\title{
Kebutuhan Psikologis Pada Pecandu Narkoba (Tinjauan Kualitatif dengan Teknik Journaling sebagai Metode Penggalian Data)
}

\author{
I Gusti Ayu Putu Wulan Budisetyani, Ni Luh Indah Desira Swandi \\ Program Studi Psikologi, Fakultas Kedokteran, Universitas Udayana \\ wulanbudisetyani@unud.ac.id
}

\begin{abstract}
Abstrak
Indonesia darurat narkoba. Jumlah penyalahguna dan pecandu narkoba di Indonesia menunjukkan peningkatan jumlah setiap tahunnya. Aparat kepolisian dan BNN (Badan Narkotika Nasional) telah berusaha untuk memutus tali peredaran narkoba dan memberikan rehabilitasi bagi para penyalahguna dan pecandu narkoba. Tetapi pada kenyataannya $70 \%$ mantan pecandu narkoba mengalami kambuh dan kembali mengonsumsi narkoba. Program rehabilitasi medis dan sosial telah diberikan kepada pecandu narkoba tetapi pada pelaksanaannya program rehabilitasi tersebut dijalankan lebih pada konsep punitive daripada rehabilitative, sehingga kebutuhan psikologis para pecandu kurang diperhatikan. Program rehabilitasi diberikan untuk memulihkan dampak fisik dan psikologis yang ditimbulkan akibat penggunaan narkoba dalam jangka waktu tertentu, seperti misalnya gangguan pada kemampuan komunikasi yang dialami pecandu. Berdasarkan paparan tersebut penelitian ini bertujuan untuk menggali kebutuhan psikologis pada pecandu narkoba dengan menggunakan metode wawancara, observasi, dan teknik journaling. Data yang didapat dianalisis melalui empat tahapan yaitu categorical aggregation, direct interpretation, mencari pola (pattern), dan naturalistic generalization. Hasil penelitian ini mendapatkan 6 kebutuhan psikologis pada pecandu narkoba yaitu need of aggression, need of abasement, need of affiliation, need of play, need of sex, need of succorance.
\end{abstract}

Kata kunci: kebutuhan psikologis, pecandu narkoba, rehabilitasi

\begin{abstract}
Indonesia has drugs emergency. Research shown the increasing of the amount of drugs abuse every year. The police officer and BNN (Badan Narkotika Nasional) has tried to break the cycle of drugs trafficking and provide rehabilition for drugs abuser and drugs addict. But in fact $70 \%$ of former drugs addict will relapse and taking drugs again. Medical dan social rehabilitation program has given to the drugs addicts but in its implementation the program is run in punitive concept than rehabilitative concept, so that will cause less attention for the psychological need of the drugs addict. Rehabilitation program given to cure the physical and psychological effects of the drugs, for example communication disorder in drugs addict. Based on that data, the purpose of this research is to get more information about the drugs addict's psychological need using interview, observation, and journaling technic methods. The data will be analized with 4 stages are categorical aggregation, direct interpretation, mencari pola (pattern), and naturalistic generalization. The result of this research show that are 6 of psychological need in drugs addict, that are need of aggression, need of abasement, need of affiliation, need of play, need of sex, need of succorance.
\end{abstract}

Keyword: psychological needs, drugs addict, rehabilitation

\section{LATAR BELAKANG}

Indonesia darurat narkoba (narkotika dan obat/bahan berbahaya). Badan Narkotika Nasional (BNN) mencatat penyalahgunaan narkoba sepanjang 2018 menyasar kepada beberapa lapisan masyarakat. Seperti kalangan mahasiswa dan para pekerja. Untuk tahun 2018, sebanyak 3,21 persen pengguna narkoba berasal dari kalangan mahasiswa (https://megapolitan.kompas.com). Hal ini merupakan salah satu siasat dari sindikat yang memerdaya anak dan remaja, yang menawarkan barang terlarang tersebut kepada seseorang dengan memberi janji-janji yang menyenangkan, yaitu "seperti di surga", "kamu pasti menjadi cerdas dan pintar", serta "nikmat yang belum pernah dirasakan" selama hidupnya (Tobing \& Hutabarat, 2009). BNN menemukan bahwa sebanyak 2.287.492 mahasiswa secara aktif menggunakan narkoba, dan untuk para pekerja yang tercatat melakukan penyalahgunaan narkoba mencapai 1.514.037 jiwa dimana angka-angka tersebut mengacu pada 40.553 kasus narkoba yang diungkap oleh BNN dan Polri tahun 2018.

Penyalahgunaan zat di Indonesia mulai muncul pada tahun 1969 dan zat disalahgunakan tidak terbatas pada jenis opioida dan ganja saja, tetapi jenis sedative/hipnotika (psikotropika) dan alkohol (minuman keras). Tidak jarang penyalah-guna memakai zat berganti-ganti dan mencampur satu jenis zat dengan zat lainnya (polydrugs abuser) (Bakthi, 2010). Menurut Hawari (dalam Bakthi, 2010) penyalahgunaan zat dapat menimbulkan dampak antara lain merusak hubungan kekeluargaan, menurunkan kemampuan belajar, ketidakmampuan untuk membedakan hal-hal yang baik dan buruk, perubahan perilaku, gangguan kesehatan, menurunnya produktivitas kerja, meningkatnya kriminalitas dan tindak kekerasan lainnya.

Penggunaan narkoba di kalangan pelajar ini juga menjadi persoalan di skala global. World Drugs Reports 2018 dari The United Nations Office on Drugs and Crime (UNODC) menemukan 5,6 persen penduduk dunia atau 275 juta orang dalam rentang usia 15 hingga 64 tahun pernah mengonsumsi narkoba minimal sekali dalam hidupnya (www.cnnindonesia.com). Di Indonesia telah diterbitkan Undang-Undang Nomor 35 Tahun 2009 tentang Narkotika yang mengamanatkan pencegahan, perlindungan, dan penyelamatan bangsa Indonesia dari penyalahgunaan narkotika serta menjamin pengaturan upaya rehabilitasi medis 
dan sosial bagi penyalah guna dan pecandu narkotika, pada Pasal 54 disebutkan bahwa "korban penyalah guna dan pecandu narkotika wajib direhabilitasi". Amanat undangundang tersebut sesuai dengan konsep penyalahgunaan narkotika dari segi kesehatan, namun belum dilakukan secara maksimal. Korban penyalah guna dan pecandu narkoba memerlukan pelayanan rehabilitasi. Jika dilihat dari segi kesehatan, penyalah guna dan pecandu narkoba merupakan suatu gangguan pada otak kronis yang dapat mengalami kekambuhan. Penyalahgunaan narkoba disebut sebagai penyakit karena memenuhi kriteria sebagai berikut, memiliki etiological agent/ agen penyebab yaitu zat psikoaktif (narkotika, psikotropika, dan zat adiktif lainnya), memiliki tanda dan gejala, serta menyebabkan perubahan struktur fungsi tubuh yang berakibat terjadinya kelainan fungsi, terutama fungsi otak sehingga dapat ditegakkan diagnosis seperti halnya penyakit yang lain sesuai dengan pengklasifikasian penyakit dalam ICD-10. Maka setiap korban penyalah guna dan pecandu narkoba berhak mendapatkan perawatan rehabilitasi (Pusat Data dan Informasi, Kementerian Kesehatan RI, 2014).

Pecandu Narkoba pada dasarnya adalah individu yang menyalahgunakan narkoba yang mengalami ketergantungan pada satu atau lebih zat narkotika, psikotropika, dan zat adiktif lainnya, baik ketergantungan secara fisik dan psikologis. Individu yang mengalami ketergantungan narkoba biasanya biasanya akan memiliki dorongan untuk terus-menerus memakai zat tersebut dan akan mengalami gejala putus zat jika pemakaiannya dihentikan. Gejala putus zat yang ditimbulkan sangat bervariasi, tergantung jenis narkoba yang digunakan, dosis pemakaian, dan jangka waktu pemakaian (Hawari, 2003). Terdapat beberapa kriteria ketergantungan zat dalam DSM-IV-TR (Davison, Neale, \& Kring, 2012), dimana tiga atau lebih dari hal-hal berikut ini harus terpenuhi yaitu toleransi, putus obat, zat digunakan dalam waktu lebih lama dan lebih banyak dari yang dimaksudkan, keinginan atau upaya untuk mengurangi atau mengendalikan penggunaannya, sangat banyak waktu yang digunakan dalam berbagai aktivitas untuk mendapatkan zat tersebut, berbagai aktivitas sosial, rekreasional, atau pekerjaan menjadi berhenti atau berkurang, terus-menerus menggunakannya meskipun menyadari bahwa berbagai masalah psikologis atau fisik menjadi semakin parah karenanya.

Ketergantungan pada narkoba dibagi menjadi dua, yaitu ketergantungan fisik adalah suatu keadaan yang ditandai oleh gangguan jasmaniah yang hebat apabila pemberian obat dihentikan. Keadaan ini timbul sebagai hasil peneysuaian diri terahdap adanya obat dalam tubuh secara terus-menerus dalam jangka waktunya yang cukup lama. Yang kedua adalah ketergantungan psikis dimana suatu keadaan dimana suatu obat menimbulkan perasaan puas dan nikmat sehingga mendorong seseorang untuk memakainya lagi secara terus menerus atau secara berkala sehingga diperoleh kesenangan/kepuasan terus menerus (Mandagi \& Wresniwiro, 1996).

Rehabilitasi yang diberikan kepada pecandu narkoba ada dua macam yaitu tahap rehabilitasi medis (detoksifikasi) dimana pada tahap ini pecandu akan diperiksa seluruh kesehatannya baik fisik maupun mental oleh dokter terlatih. Kemudian akan diputuskan apakah pecandu perlu diberikan obat tertentu untuk mengurangi gejala putus zat (sakau) yang dialami. Pemberian obat tergantung dari jenis narkoba dan berat ringannya gejala putus zat. Dalam hal ini dokter memerlukan kepekaan, pengalaman, dan keahlian khusus guna mendeteksi gejala kecanduan tersebut. Tahap yang kedua adalah rehabilitasi nonmedis. Tahap ini pecandu ikut dalam program rehabilitasi. Di Indonesia sudah dibangun tempat-tempat rehabilitasi, sebagai contoh di bawah BNN adalah tempat rehabilitasi di daerah Lido (Kampus Unitra), Baddoka (Makassar), dan Samarinda. Di tempat rehabilitasi ini, pecandu menjadi berbagai program diantaranya program Therapeutic Communities (TC), 12 steps (dua belas langkah), pendekatan keagamaan, dll. Tahap selanjutnya adalah bina lanjut (after care) dimana tahap ini pecandu diberikan kegiatan sesuai dengan minat dan bakat untuk mengisi kegiatan sehari-hari. Pecandu dapat kembali ke sekolah atau tempat kerja namun tetap berada di bawah pengawasan (https://rehabilitasi.bnn.go.id).

Walaupun dampak negatifnya cukup banyak, fakta yang menyertai juga mengungkap bahwa kecenderungan pecandu narkoba untuk kembali menggunakan narkoba atau relapse cukup tinggi. Sekitar 70 persen dari jumlah pecandu narkoba yang telah menyelesaikan program rehabilitasi dari BNN cenderung mengulangi penyalahgunaan obat-obatan terlarang. Kekambuhan atau relapse adalah suatu proses yang terjadi karena faktor pemicu dimana seseorang telah dinyatakan abstinence (sembuh) dan kembali menggunakannya. Relapse dimulai dari suatu perubahan pada pikiran, perasaan, dan perilaku atau dengan kata lain suatu kerinduan (sugesti) pada sesuatu, baik disadari ataupun tidak. Kekambuhan adalah hal yang sangat umum terjadi pada pecandu narkoba setelah proses rehabilitasi, dimana 90 hari setelah lepas dari masa perawatan detoksifikasi merupakan masa yang paling rawan bagi pecandu untuk kembali mengonsumsi narkoba (Doweiko, 1999).

Waty (2016) mengungkapkan dari hasil penelitian yang telah dilakukan bahwa faktor kemudahan memperoleh narkoba, alat yang mengingatkan masa lalu, pemulihan yang pernah dijalani, dukungan keluarga, dukungan sosial, dan pengaruh teman berperan dalam penyebab terjadinya relapse. Selain itu Rachmawati (2010) juga memaparkan bahwa bahwa mantan pengguna narkoba yang kembali kambuh (relapse) menggunakan narkoba dan mengalami berbagai perubahan kemunduran pada pikiran, emosi dan perilakunya merupakan bentuk penghindaran diri (avoidance) dari lingkungan, masalah, dan konflik yang dialami partisipan. Adanya konflik batin yang dirasakan partisipan membuat mereka sulit berpikir positif untuk menyelesaikan masalah dengan benar sehingga membuat mereka memilih melarikan diri (respon flight) dan menghindar dari masalah yang dihadapi dengan kembali menggunakan narkoba agar kembali merasa tenang, nyaman, dan bebas dari masalah yang dihadapi.

Hasil studi pendahuluan terhadap seorang pecandu narkoba di Bali dengan inisial PR, seorang perempuan berusia 24 tahun yang tertangkap oleh pihak kepolisian juga mengungkapkan bahwa dirinya berulang kali putus sambung dalam menggunakan narkoba. Setiap kali kambuh (relapse) dosis penggunaan narkoba yang dikonsumsi juga meningkat agar mendapatkan efek yang diinginkan. Selain terjadi peningkatan dosis dan frekuensi penggunaan, PR juga menggunakan 
beberapa jenis narkoba setiap harinya secara bersama-sama. Latar belakang yang menyebabkan PR seringkali jatuh kembali menggunakan narkoba adalah keinginan untuk melupakan sejenak masalah-masalah yang dihadapi di dalam keluarganya serta perasaan nyaman yang dialami pada saat PR mengonsumsi narkoba (Budisetyani, 2019).

Penggunaan narkoba secara terus-menerus tentu saja menimbulkan dampak pada individu yang bersangkutan. Terhadap beberapa dampak yaitu dampak terhadap fisik yang berupa kerusakan pada sel-sel otak, syaraf, pembuluh darah, darah, tulang, dan seluruh jaringan pada tubuh manusia. Semua penderitaan yang dialami akibat penyakit seperti tersebut di atas mendatangkan dampak pada mental yaitu perubahan sifat, sikap, dan perilaku. Pemakai narkoba berubah menjadi tertutup karena malu akan dirinya, takut mati, atau takut perbuatannya diketahui. Karena menyadari buruknya perbuatan yang ia lakukan, pemakai narkoba berubah menjadi pemalu, rendah diri, dan sering merasa sebagai pecundang, tidak berguna, dan sampah masyarakat. Sebagai akibat dari adanya 3 sifat narkoba yang khas, yaitu habitual, adiktif, dan toleran, pemakai narkoba dapat berubah menjadi orang yang egois, eksklusif, paranoid (selalu curiga dan bermusuhan), psikosis, bahkan tidak peduli terhadap orang lain (Partodiharjo, 2008).

Kambuh atau relapse merupakan suatu tantangan dari proses panjang menuju kesembuhan penuh dari seorang pecandu narkoba. Kendati mantan pecandu sudah dapat lepas dari ketergantungan narkoba untuk jangka waktu tertentu, tetapi kecenderungan untuk menggunakan narkoba masih akan terasa. Sugesti tersebut bisa dipicu secara mendadak dan tak terkendalikan, bila kondisi psikologis individu mulai kacau. Berdasarkan hal tersebut, banyak ahli berpendapat bahwa sugesti untuk kembali menggunakan narkoba adalah bagian dari ketergantungan (Pusat Data dan Informasi, Kementerian Kesehatan RI, 2014). Sebagai langkah antisipasi, BNN membuat program pasca rehabilitasi selama dua bulan untuk mempersiapkan mantan pecandu kembali bersinergi ke dalam komunitas.

Apabila pecandu narkoba juga sedang menjalani masa hukuman maka rehabilitasi juga akan dilakukan di lembaga pemasyarakatan. Meski mengusung konsep rehabilitasi, pada prakteknya rehabilitasi masih dijalankan dengan konsep punitive daripada rehabilitative. Orientasi pembinaan lebih bersifat top down approach, yaitu program sudah ditetapkan dan seluruh narapidana harus berpartisipasi. Hasil dari pembinaan tersebut membuat narapidana hanya sebagai objek program, sehingga kebutuhan narapidana dalam membangun diri dan kelompok tidak diperhatikan (Yunardhani, 2009). Konsekuensinya adalah kebutuhan psikologis para pecandu cenderung kurang diperhatikan.

Berdasarkan paparan di atas dapat dilihat bahwa pada dasarnya semua manusia memiliki kebutuhan, bahkan pecandu narkoba juga memilikinya. Setiap kebutuhan yang dimiliki manusia secara khas seringkali disertai dengan perasaan atau emosi tertentu dan disertai pula dengan tindakan-tindakan instrumental tertentu yang efektif untuk menghasilkan situasi akhir yang diinginkan (Murray dalam Hall \& Lindzey, 1993). Murray mengemukaan dua tipe kebutuhan yaitu (a) kebutuhan primer/kebutuhan viskerogenik yang berhubungan dengan peristiwa-peristiwa organis tertentu yang khusus dan berkenaan dengan kepuasan fisik. Seperti misalnya kebutuhan akan air, udara, makanan, seks, laktasi, buang air besar,dan buang air kecil. (b) kebutuhan sekunder/kebutuhan psikogenik yang berasal dari kebutuhan primer dan dan ditandai dengan tidak adanya hubungan dengan kepuasan fisik tertentu.

Murray mengemukakan dua tipe kebutuhan yaitu (a) kebutuhan primer/kebutuhan viskerogenik yang berhubungan dengan peristiwa-peristiwa organis tertentu yang khusus dan berkenaan dengan kepuasan fisik. Seperti misalnya kebutuhan akan air, udara, makanan, seks, laktasi, buang air besar,dan buang air kecil. (b) kebutuhan sekunder/kebutuhan psikogenik yang berasal dari kebutuhan primer dan dan ditandai dengan tidak adanya hubungan dengan kepuasan fisik tertentu. Bagian-bagian kebutuhan psikogenik menurut Murray adalah (a) need of abasement yaitu tunduk secara pasif tehadap kekuatan luar, menerima perlakukan yang tidak adil, kritik dan hukuman, menyerah, menyalahkan, meremehkan, merendahkan diri sendiri, merusak diri sendiri, mencari dan menikmati penderitaan, hukuman penyakit dan kemalangan. (b) need of achievement yaitu menyelesaikan sesuatu yang sulit, mengunggulkan diri, menyaingi dan mengungguli orang lain,meningkatkan harga diri dengan menyalurkan bakat secara berhasil. (c) need of affiliation yaitu membuat senang dan mencari afeksi dari objek yang disukai, patuh dan tetap setia pada teman, menjalin persahabatan. (d) need of aggression yaitu menghadapi perlawanan dengan kekerasan, melawan, membalas perbuatan yang tidak adil, menyerang, melukai, melawan dengan kekerasan, atau menghukum individu lain. (e) need of autonomy yaitu menolak untuk dipaksa atau dilarah, bebas, menghindari atau meninggalkan kegiatan yang ditentukan oleh otoritas yang menguasai, tidak terikat, tidak bertanggung jawab. (f) need of counteraction yaitu menguasai atau memerbaiki kegagalan dengan berjuang lagi, menghilangkan pelecehan dengan memulai tindakan, menekan perasaan takut, memertahankan harga diri dan kebanggaan pada taraf yang tinggi. (g) need of defendance yaitu memertahankan diri terhadap serangan atau kritik, menyembunyikan atau membenarkan perbuatan tercela, kegagalan atau penghinaa. (h) need of deference yaitu memuji, menghormati, atau menyanjung, dengan senang hati tunduk pada pengaruh orang lain yang dikenal, menyesuaikan diri dengan kebiasaan. (i) need of dominance yaitu memengaruhi atau mengarahkan tingkah laku orang lain dengan saran, bujukan, imbauan, atau perintah; mencegah, menghambat, atau melarang. (j) need of exhibition yaitu menciptakan kesan; senang dilihat dan didengar; membuat orang lain kagum, terpesona, terhibur, terkejut, ingin tahu, senang, atau terpikat. (k) need of harm avoidance yaitu menghindari rasa sakit, luka fisik, penyakit dan kematian; melarikan diri dari situasi berbahaya; mengambil tindakan pencegahan, kebutuhan akan rasa aman. (l) need of in avoidance yaitu menghindari penghinaan, meninggalkan situasi yang memalukan atau menghindari kondisi yang bisa menimbulkan pelecehan: caci maki, ejekan, atau sikap masa bodoh orang lain; menahan diri untuk bertindak karena takut gagal. (m) need of nurturance yaitu memberi simpati dan memuaskan kebutuhan objek yang tidak berdaya: bayi, objek yang lemah atau cacat, ragu-ragu, kalah, dihina, kesepian, patah hati, sakit, bingung, membantu objek yang dalam bahaya; member makanan, membantu, menghibur, melindungi (n) need of order yaitu mengatur 
barang; menjaga kebersihan, susunan, keseimbangan, keteraturan, ketelitian. (o) need of play yaitu berbuat untuk kesenangan tanpa tujuan lebih lanjut; suka tertawa dan membuat lelucon, mengambil bagian dalam permainan, olahraga, pesta, bermain kartu. (p) need of rejection yaitu memisahkan diri dari objek yang tidak disenangi, mengucilkan, melepaskan, mengusir atau bersikap masa bodoh terhadap objek yang lebih rendah; menghina atau memutuskan hubungan cinta dengan objek. (q) need of sentience yaitu mencari dan menikmati kesan-kesan yang menyentuh perasaan, kesan yang menyenangkan. ( $r$ ) need of sex yaitu menjalin dan meningkatkan hubungan erotic. Mengadakan hubungan seksual. (s) need of succorance yaitu memuaskan kebutuhan-kebutuhan dengan bantuan simpatik dari objek yang dikenal; dirawat, didukung, dikelilingi, dilindungi, dicintai, dinasehati, dibimbing, dimanjakan, diampuni, dihibur; menempel pada seorang pelindung setia, selalu memiliki seorang pendukung. ( $\mathrm{t}$ ) need of understanding yaitu menanyakan atau menjawab pertanyaan umum; tertarik pada teori; memikirkan, merumuskan, menganalisis, dan menggeneralisasikan. Dari paparan tersebut dapat disimpulkan bahwa kebutuhan psikologis adalah perilaku individu untuk memenuhi perasaan atau kepuasan yang bersifat psikologis, seperti misalnya kebutuhan akan mencapai prestasi, afiliasi, agresi, otonomi, dan lain lain.

Perubahan perilaku manusia yang diakibatkan oleh penggunaan narkoba dalam jangka waktu tertentu tentu saja juga memengaruhi kemampuan komunikasi dari individu tersebut. Sehingga bentuk-bentuk komunikasi konvensional secara verbal juga seringkali menemui kesulitan. Bentuk komunikasi dapat saja menggunakan cara alternatif secara non-verbal atau tertulis. Salah satunya adalah teknik journaling. Menulis jurnal (catatan harian) memungkinkan individu untuk mengungkapkan dan mengeksternalisasikan pikiran, perasaan, kebutuhan, dan ekspresi yang biasanya disimpan untuk ranah internal pribadi (Erford, 2016). Kerner dan Fitzpatrick (dalam Erford, 2016) membagi dua tipe penulisan terapeutik, yaitu afektif/emosional dan kognitif/kontruktivis. Journaling afektif memungkinkan individu untuk menuliskan ide-ide yang mengalir bebas dengan tujuan eksptersi dan pelepasan emosional. Sedangkan journaling kognitif adalah pendekatan menulis yang lebih terstruktur yang memfokuskan pada kognisi individu dan menciptakan-makna.

Pecandu sebagai manusia juga memiliki hak dan kebutuhan dasar untuk mencapai kepulihan dari narkoba secara total. Oleh karena itu, penelitian tentang kebutuhan psikologis pada pecandu narkoba ini penting dilakukan sebagai salah satu upaya untuk menurunkan angka kekambuhan (relapse) yang kerap kali terjadi.

\section{METODE PENELITIAN}

\section{Tipe Penelitian}

Penelitian ini menggunakan metode kualitatif dengan pendekatan studi kasus. Bogdan \& Biklen (dalam Ahmadi, 2014) menyatakan penelitian studi kasus merupakan suatu kajian yagn rinci tentang satu latar, atau subjek tunggal, atau satu tempat penyimpanan dokumen, atau suatu peristiwa tertentu. Stake (dalam Creswell, 2007) mengemukakan bahwa dalam penelitian studi kasus, kasus-kasus dibatasi oleh waktu dan aktivitas dan peneliti mengumpulkan informasi secara lengkap dengan menggunakan berbagai prosedur pengumpulkan data berdasarkan waktu yang telah ditentukan.

\section{Unit Analisis}

Penelitian ini menggunakan unit analisis yang bersifat individual. Pada penelitian didapatkan data bagaimana kasus individu yaitu pada pecandu narkoba didapatkan informasi mengenai kebutuhan-kebutuhan psikologisnya. Pada penelitian ini untuk mendapatkan data yang lengkap maka digunakan teknik journaling sebagai sarana komunikasi antara peneliti dan responden karena pecandu narkoba cenderung sulit untuk diajak berkomunikasi yang merupakan salah satu dampak dari penggunaan narkoba dalam jangka waktu tertentu.

\section{Responden Penelitian}

Responden penelitian ini adalah satu orang pecandu narkoba berjenis kelamin perempuan yang dipilih dengan menggunakan teknik purposive sampling. Beberapa kriteria responden ini adalah: (1) Berjenis kelamin laki-laki atau perempuan, (2) sudah dinyatakan sebagai pecandu narkoba oleh Tim Asesmen Terpadi Badan Narkotika Nasional, (3) mengonsumsi narkoba lebih dari 1 jenis zat, (4) belum pernah menjalani rehabilitasi medis dan sosial.

\section{Teknik Pengumpulan Data}

Proses pengumpulan data pada penelitian ini dilakukan dengan teknik observasi, wawancara, dan studi dokumentasi berupa jurnal atau catatan yang dibuat oleh responden. Observasi yang dilakukan adalah observasi terfokus dan wawancara semi-terstruktur. Menurut Moleong (dalam Prastowo, 2016) studi dokumentasi yang digunakan adalah dokumen pribadi yaitu catatan atau karangan seseorang secara tertulis tentang tindakan, pengalaman, dan kepercayaannya. Pada penelitian ini responden diminta untuk membuat jurnal (jurnal/catatan harian) yang dibuat sesuai dengan instruksi setiap hari selama 30 hari.

\section{Teknik Pengorganisasian dan Analisis Data}

Teknik pengorganisasian data dilakukan dengan cara memindahkan data rekaman wawancara ke dalam satu berkas pada komputer. Selain itu pengambilan data yang didapatkan dari teknik journaling (menulis jurnal/catatan harian) yang dilakukan oleh responden akan dipindahkan ke dalam satu berkas pada komputer yang telah diberi judul sesuai dengan kode. Selanjutnya semua data yang terkumpul dianalisis melalui empat tahapan (Stake dalam Creswell, 2007) yaitu categorical aggregation, direct interpretation, mencari pola (pattern), dan naturalistic generalization.

\section{Kredibilitas Penelitian}

Kredibilitas data pada penelitian ini dilakukan dengan peningkatan ketekunan, diskusi teman sejawat, dan triangulasi waktu (Emzir, 2012).

\section{Isu Etik}

Isu etik yang harus diperhatikan selama proses penelitian ini antara lain no harm, confidentiality, privacy, informed consent to research.

\section{HASIL PENELITIAN}

Responden dalam penelitian ini adalah seorang pecandu multiple zat berjenis kelamin perempuan berusia 24 tahun 
dengan inisial PR. Responden tinggal bersama pacar responden yang merupakan warganegara asing dan terpisah rumah dengan responden. Responden mulai mengonsumsi narkoba sejak usia 14 tahun karena melihat kakak kandung yang sedang juga mengonsumsi narkoba. Terdapat 3 zat adiktif yang digunakan responden sebelum tertangkap aparat kepolisian.

Berdasarkan hasil wawancara, observasi, dan studi dokumen melalui jurnal/catatan harian yang telah dilakukan, peneliti menemukan 10 kategori yang berhubungan dengan kebutuhan psikologis pada pecandu narkoba.Kategori ini kemudian dikelompokkan berdasarkan hasil studi dokumen dan observasi. 10 kategori tersebut membentuk 2 pola, yaitu:

Pola 1. Faktor Penyebab, yaitu:

a. Perlakuan ayah kepada responden,

Responden menuturkan dalam tulisannya bahwa dirinya saat ini sangat merindukan sosok ayah,

"andaikan ayah ada di sampingku setiap hari, dunia tidak akan terasa serumit ini"

"bila Tuhan ijinkan kelak aku berjodoh dengan laki-laki yang sangat pengertian seperti ayah, aku akan sangat bersyukur dan aku berjanji akan berhenti dari dunia laknat ini”

"terima kasih Tuhan, tadi malam Kau ijinkan aku bertemu ayah walau hanya lewat mimpi, walau hanya sebentar"

Setiap kali kakak responden memukuli responden karena tidak memberinya uang, maka ayah yang akan mengobati luka-luka pada badan responden. Saat responden pulang ke rumah dalam keadaan mabuk, ibu responden pasti akan marah dan mengomeli responden sangat lama, setelah itu ayah pasti memberinya susu hangat sebelum responden masuk ke dalam kamar.

"ayah yang selalu ada untukku. Dia tak pernah lelah memahamiku. Hanya dia (ayah) yang selalu tersenyum padaku"

"aku sayang ayah. Maafkan aku ayah. Aku tau kalau kelakuanku parah banget dulu, ayah yang selalu buat aku merasa adem tiap kali mamah ngomelin aku, ayah yang mau untuk balurin obat ke kakiku tiap kali Mas E pukulin aku"

b. Perlakuan ibu kepada responden,

Ibu sangat sering memarahi responden, terutama saat responden sedang menunjukkan perilaku yang tidak disukai ibu.

"mungkin ada dosaku dimasa lalu yang bikin ibu tak pernah mengerti keadaanku"

"aku ngga ngerti apa maunya (ibu) dia terus marah, selalu marah, setiap saat.....setiap saat. Coba ibu mau buka sedikit mata hatinya, entah apa yang menutupinya"

"Tuhan, aku capek melilhatnya (ibu) terus menerus menyalahkanku atas semua ini. Apa ibu ngga sayang sama aku ya."

"mana ada ibu yang diem aja ngeliat anak perempuannya digebukin kayak gitu...aku jadi berpikir apakah aku bukan anak kandungnya."

Hampir setiap hari ibu selalu marah dan mengeluarkan katakata makian kepada responden. Saat responden dipukuli oleh kakak, ibu mendiamkan saja perilaku kakak dan tidak sedikitpun membela responden.

c. Perlakukan kakak kandung kepada responden.

Kakak kandung responden mengalami kecanduan alkohol. Kakak selalu meminta uang kepada responden untuk membeli alkohol setiap hari. Jika tidak diberi uang, responden selalu dipukul dan diseret oleh kakak.

"sebenernya aku sayang dia (kakak), Tuhan. Tapi kenapa Kau beri dia kemarahan-kemarahan seperti itu. Aku kasihan sama dia, sama istrinya. Biarkan kami hidup tenang, Tuhan"

"suatu saat dia (kakak) pasti akan mendapatkan karmanya. Dia sudah terlalu sering membuat aku sakit. Aku capek terus menerus dipukulin, dia pasti akan dipukulin orang pula suatu saat nanti."

"tiap kali butuh uang....selalu aku yang dicarinya. Tapi saat bahagia, aku tak pernah dikabarinya. Dunia tak adil. Kenapa selalu aku yang harus memberinya uang untuk mabuk...”

d. Perlakuan pacar kepada responden.

Pacar responden selalu memberikan perintah yang harus dikerjakan oleh responden. Apabila permintaan pacar tidak dipenuhi, maka responden akan diperlakukan semena-mena oleh pacar, seperti dibentak, ditampar, dan dijambak.

"aku masih mencari jawabannya kenapa aku dipertemukan dengan dia (pacar) oleh Tuhan. Apakah aku masih memiliki hutang karma dengannya?"

"entah sampai kapan aku terus menerus menderita seperti ini karenanya (pacar). Dia sangat mirip dengan mas E (kakak responden). Aku ngga pernah bisa bahagia dengannya."

"apakah wajar jika manusia selalu menyakiti orang lain jika kata-katanya tidak diturutin? Apakah benar ini Tuhan? Aku capek diperintah seperti gundiknya. Aku capek selalu diperlakukan seperti ini. Aku mau lepas ..... beri tahu aku caranya, Tuhan"

Responden juga berkeinginan untuk menghentikan hubungan dengan pacarnya tetapi tidak bisa dan belum menemukan caranya, karena pacar responden pasti akan menyakitinya lagi jika responden meminta putus.

\section{Pola 2. Kebutuhan Psikologis pecandu narkoba yaitu:}

a. Need of aggression

"Tuhan tau sudah berapa kali aku mencoba ingin bertemu denganNya. Berapa kali aku harus berurusan dengan rumah sakit dan kantor polisi."

"tiap kali aku sedih, stress, sendiri, aku merasa bahwa hidupku sudah berakhir. Tiap kali aku melihat silet dan gunting, entah kenapa rasanya selalu terus ingin untuk mengakhiri hidup." "... saat aku mau gantung diri, ayahku yang berteriak saat itu. Padahal saat itu sudah dekat sekali aku ingin mengakhiri hidup"

Responden pernah menyilet tangannya dekat dengan nadi saat berada di kamar mencoba untuk bunuh diri. Ia juga pernah mencoba untuk bunuh diri dengan cara gantung diri di kusen pintu gudang rumahnya tetapi ayahnya menghalangi niat tersebut.

\section{b. Need of abasement}

"aku manusia tanpa daya. Semua memperbudakku. Narkoba memperbudakku. Mas E menjadikan aku lumbung uangnya. Ibu menjadikan aku pelampiasan stresnya."

"aku ngga pernah bisa untuk membalas perlakuan mereka semua. Semuanya... semuanya.. mas E, ibu, R semuanya senang banget bisa menyakiti aku."

Responden selalu menuruti perintah pacarnya yang selalu memberinya narkoba secara gratis, tidak pernah membalas perlakuan kakak kandungnya yang sering memukul dan 
menyeret responden jika tidak memberi uang, responden selalu menghadapi kemarahan ibu jika responden tidak patuh. c. Need of affiliation ..

"Tuhan tau..., Dia kasih aku dunia yang luas. Teman-teman yang baik tetapi jauh. Andaikan mereka (teman-teman) tau aku masuk kayak gini..., aku yakin mereka akan bantu aku. Mereka akan tengokin aku. Dan mereka akan belain aku" "Tuhan boleh tolong aku, kasih tau mereka (teman-teman) bahwa aku sedang masuk disini”,

"....Tuhan tau aku suka sabu... Dia kasih aku teman-teman yang juga suka sabu. Jika bukan info dari mereka, aku juga ngga tau cara pake yang simpel banget, cara menikmati dengan bentuk yang lain"

Responden memiliki beberapa teman dari luar negeri yang menjadi tempatnya untuk berkeluh kesah dan sering memberi informasi kepada responden mengenai jenis-jenis narkoba baru.

\section{d. Need of play}

"ya aku tau, pergi dugem sering-sering juga salah. Tapi hanya itu caraku bisa lupa dengan masalahku. Kemana lagi aku bisa pergi..."

"dengan sabu aku nyaman. Aku merasa lebih happy. Aku merasa hidup jadi lebih bersemangat. Adakah yang bisa menggantikannya."

"sabu, wisky, cimeng... kalau boleh aku rindu pada kalian. Mabuk mabuk mabuk.... asyik dan bebas rasanya."

Responden sering mengunjungi tempat hiburan malam, minum minuman beralkohol sampai mabuk, dan mengonsumsi narkoba untuk melupakan masalah yang mengganggu pikirannya.

\section{e. $\quad$ Need of sex}

"Tuhan, aku tau, aku tidak boleh melakukan ini. Tapi hanya mereka yang bisa memperlakukan aku dengan manis. Boleh kan sekali kali aku ini ingin dipeluk. Dimanja. Disayang."

". kalaupun tiap malam aku tidur dengan orang yang berbeda, aku tetep ngga pengen dibilang perempuan nakal. Aku hanya mencari kenyamanan. Apakah salah?”

responden sering berganti-ganti pasangan dalam melakukan hubungan seksual dimana pasangan tersebut ditemuinya di tempat hiburan malam.

\section{f. Need of succorance}

"aku tau dia (pacar) yang kasih aku uang. Kasih aku barang. Kasih aku motor. Banyak banget. Aku makin ngerasa sulit. Tuhan tau hidupku berkecukupan dengan R (pacar). Dia kasih aku banyak banget barang. Uang yang lebih dari cukup."

"apakah hutang budi namanya jika aku menggunakan barangbarang yang dia beri untukku. Aku ngga pernah ketinggalan model terbaru kan.... aku senang “

Responden memiliki pasangan tetap yang selalu memberinya uang untuk memenuhi kebutuhan hidupnya, memberinya tempat tinggal, dan fasilitas seperti kendaraan dan gawai.

\section{PEMBAHASAN DAN KESIMPULAN}

Berdasarkan hasil data yang diperoleh selama proses penelitian berlangsung, peneliti menemukan dua pola yang membentuk 10 kategori terkait dengan kebutuhan psikologis pada pecandu narkoba melalui wawancara dan observasi dengan menggunakan metode teknik journaling. Teknik journaling membantu individu untuk mengingat kejadian- kejadian dan contoh-contoh penting yang terjadi sehingga memungkinkan peneliti untuk mengakses kejadian-kejadian dan informasi kritis di luar sesi wawancara (Edford, 2015). Selain itu dengan teknik journaling, individu akan terbantu untuk mengekspresikan emosi, meningkatkan kesadaran tentang sumber daya dan kekuatan personalnya, membantu memisahkan masalah dari dari, menurunkan gejala dan perilaku bermasalah, serta membantu perkembangan perasaan berdaya (Keeling \& Bermundez dalam Edford, 2016). 10 kategori yang berada dalam dua pola yang didapat adalah:

Pola 1. Faktor Penyebab Pada Pecandu Narkotika

a. Perlakuan Ayah kepada responden

Ayah selalu bersikap netral dan penuh perhatian kepada subjek. Responden menganggap ayah adalah sosok penolong dan yang paling memahami keadaan responden. Walaupun ayah tidak pernah membela ataupun menghentikan perbuatan kakak kepada responden, tetapi ayah selalu ada di samping responden setelah peristiwa-peristiwa yang menyakitkan bagi responden.

b. Perlakukan Ibu kepada responden

Ibu selalu berseberangan pendapat dengan responden. Responden menganggap ibu adalah sosok yang tidak pernah memahami keadaan responden. Disamping itu, responden juga merasa bingung mengapa sang ibu selalu memperlakukan dirinya seperti tidak adil dengan kakak responden, responden mengaitkan perilaku ibunya terkait dengan karma dengan dirinya.

c. Perlakuan kakak kandung kepada responden

Kakak selalu memperlakukan responden secara kasar apabila tidak diberi uang. Responden merasa lelah selalu diperlakukan tidak baik oleh kakaknya dan berharap sang kakak akan mendapatkan karma dari segala perbuatan yang telah dilakukannya kepada responden. Walaupun demikian, responden sebenarnya juga merasakan sayang kepada kakak kandungnya.

d. Perlakuan pacar kepada responden

Pacar responden selalu memperlakukan responden dengan kasar apabila perintah pacar tidak dilakukan oleh responden. Responden memiliki keinginan untuk memutuskan hubungan dengan pacar tetapi takut akan disakiti lagi secara fisik oleh pacarnya.

Pola 2. Kebutuhan Psikologis pecandu narkoba yaitu:

a. Need of aggression (responden selalu menyakiti diri sendiri dengan cara menyilet nadi atau mencoba bunuh diri dengan memasang tali di kusen pintu dan kursi untuk menggantung diri setiap kali mengalami masalah yang berhubungan dengan keluarga),

b. Need of abasement (responden selalu menuruti perintah pacarnya yang selalu memberinya narkoba secara gratis, tidak pernah membalas perlakuan kakak kandungnya yang sering memukul dan menyeret responden jika tidak memberi uang, responden selalu menghadapi kemarahan ibu jika responden tidak patuh),

c. Need of affiliation (responden memiliki beberapa teman dari luar negeri yang saat ini menjadi tempatnya untuk berkeluh kesah dan sering member informasi kepada responden mengenai jenis-jenis narkoba baru),

d. Need of play (responden sering mengunjungi tempat hiburan malam, mabuk, dan mengonsumsi narkoba untuk melupakan masalah yang mengganggu pikirannya), 
e.Need of sex (responden sering berganti-ganti pasangan dalam melakukan hubungan seksual dimana pasangan tersebut ditemuinya di tempat hiburan malam),

f. Need of succorance (responden memiliki pasangan tetap yang selalu memberinya uang untuk memenuhi kebutuhan hidupnya, memberinya tempat tinggal, dan fasilitas seperti kendaraan dan gawai).

Berdasarkan hasil penelitian yang telah dilakukan, maka dapat disimpulkan bahwa terdapat 6 kebutuhan psikologis pada pecandu narkoba yaitu:

a. Responden selalu menyakiti diri sendiri dengan cara menyilet nadi atau mencoba bunuh diri dengan memasang tali di kusen pintu dan kursi untuk menggantung diri setiap kali mengalami masalah yang berhubungan dengan keluarga (need of aggression),

b. Responden selalu menuruti perintah pacarnya yang selalu memberinya narkoba secara gratis, tidak pernah membalas perlakuan kakak kandungnya yang sering memukul dan menyeret responden jika tidak memberi uang, responden selalu menghadapi kemarahan ibu jika responden tidak patuh (need of abasement),

c. Responden memiliki beberapa teman dari luar negeri yang saat ini menjadi tempatnya untuk berkeluh kesah dan sering member informasi kepada responden mengenai jenisjenis narkoba baru (need of affiliation),

d. Responden sering mengunjungi tempat hiburan malam, mabuk, dan mengonsumsi narkoba untuk melupakan masalah yang mengganggu pikirannya (need of play),

e. Responden sering berganti-ganti pasangan dalam melakukan hubungan seksual dimana pasangan tersebut ditemuinya di tempat hiburan malam (need of sex),

f. Responden memiliki pasangan tetap yang selalu memberinya uang untuk memenuhi kebutuhan hidupnya, memberinya tempat tinggal, dan fasilitas seperti kendaraan dan gawai (need of succorance).

Melalui teknik journaling yang digunakan sebagai salah satu metode wawancara dalam penelitian ini, responden dapat dengan bebas mengungkapkan dan menyalurkan emosi yang sedang dirasakannya. Masing-masing catatan harian dirancang sesuai dengan tujuan dan informasi yang diingin digali.

Saran yang dapat diberikan untuk keluarga dengan anak pecandu narkoba adalah diharapkan dapat mengenal dan memahami kebutuhan psikologis yang dimiliki seorang pecandu narkoba sehingga pemahaman tersebut dapat dijadikan acuan dalam menghadapi dan membantu pemulihan pecandu narkoba agar tidak kembali kambuh.

Saran bagu praktisi rehabilitasi untuk pecandu narkoba adalah dapat menggunakan metode teknik journaling sebagai media yang dapat membantu memahami kebutuhan psikologis pecandu yang kemudian hasilnya dapat digunakan sebagai dasar pembuatan program rehabilitasi yang sesuai dengan kebutuhan psikologis pecandu narkoba.

Saran bagi peneliti selanjutnya adalah dapat menambahkan jumlah responden terkait dengan kebutuhan psikologis pada pecandu narkoba dan dapat merancang teknik journaling yang lebih bervariatif.

\section{DAFTAR PUSTAKA}

Ahmadi, R. (2014). Metodologi penelitian kualitatif. Yogyakarta: Ar-Ruzz Media

Anonim. (2019 Mei). Tahap-tahap pemulihan pecandu narkoba. Diunduh dari https://rehabilitasi.bnn.go.id/public/articles/read/267 tanggal $\underline{30 \text { Juni } 2019}$

Anonim. (2019 Juni). Survei BNN: 23 juta pelajar konsumsi narkoba. Diunduh dari https://www.cnnindonesia.com/nasional/20190622182557-20405549/survei-bnn-23-juta-pelajar-konsumsi-narkoba tanggal 30 Juni 2019

Bakthi, D. (2010). Pencegahan terhadap bahaya narkoba (narkotika dan obat-obat terlarang). Bandung: Sinergi Pustaka Indonesia.

Budisetyani, IG.A.P.W. (2019). Studi Pendahuluan: riwayat hidup pecandu narkoba. Denpasar: Tidak dipublikasikan.

Creswell, J.W. (2007). Qualitative inquiry and research design: choosing aming five approach, second edition. London: Sage.

Davison, G.C., Neale, J.M., Kring, (2012). Psikologi abnormal edisi ke-9. Depok: PT Raja Grafindo Persada

Erdford, B.T. (2016). 40 teknik yang harus diketahui setiap konselor. Edisi kedua.Yogyakarta: Pustaka Pelajar

Emzir. (2012). Analisis data: metodologi penelitian kualitatif. Jakarta: Rajawali Pers.

Doweiko, H.E (1999). Concepts of chemical dependency. CA : Brooks/Cole Pub. Co.

Hall, C.S \& Lindzey, G. (1993). Psikologi kepribadian 2: teori-teori holistic (organismic-fenomenologis). Alih bahasa A. Supratiknya. Yogyakarta: Kanisius.

Hawari, 2003. Pendekatan holistik pada gangguan jiwa skizofrenia. Jakarta: Gaya Baru

Partodiharjo, S., (2008). Kenali narkoba dan musuhi penyalahgunaannya. Jakarta: Esensi

Mandagi, J. \& Wresniwiro, M. (1996). Masalah narkotika dan zat adiktif lainnya serta penanggulangannya.

Marison, W. (2019 Maret). BNN sepanjang 2018, 2 juta mahasiswa dan 15 juta pekerja terlibat narkoba. Diunduh dari https://megapolitan.kompas.com/read/2019/03/25/10215681/b 
nn-sepanjang-2018-2-juta-mahasiswa-dan-15-juta-pekerjaterlibat-narkoba tanggal 1 Mei 2019

Prastowo, A. (2016). Metode penelitian kualitatif dalam perspektif rancangan penelitian. Jogjakarta : Ar-Ruzz Media.

Pusat Data dan Informasi, Kementerian Kesehatan RI (2014). Gambaran umum penyalahgunaan narkoba di Indonesia. Buletin Jendela Data dan Informasi Kesehatan Semester 1. ISSN: 2088-270X diunduh tanggal 30 Juni 2019

Rachmawati, S. (2010). Relapse (kambuh) pada mantan pengguna napza (sebuah studi fenomenologi). (Skripsi tidak dipublikasikan). Fakultas Psikologi Universitas Islam Negeri
Sultan Syarif Kasim Riau. Diunduh http://repository.uinsuska.ac.id/11582/1/2010_201027PSI.pdf tanggal 2 Juli 2019

Tobing, J.H.L \& Hutabarat, U. (2009). Nikmat membawa sengsara. Bandung: Indonesia Publishing House.

Waty, E. (2016). Gambaran penyebab kekambuhan kembali (relapse) pada pecandu narkoba dip anti rehabilitasi narkoba doulos Jakarta timur tahun 2016. Diunduh dari https://digilib.esaunggul.ac.id/UEU-Undergraduate$\underline{201431218 / 7482}$ tanggal 30 Juni 2019

Yunardhani, R. (2010). Efektivitas Lembaga Permasyarakatan Di Indonesia. Jurnal Sosiologi .Vol . 15. Nomor 2 